\title{
Control of Respiratory Diseases in Patients with Amyotrophic Lateral Sclerosis During the COVID-19 Pandemic
}

\author{
Guilherme Gomes Azizi ${ }^{1}$, Marco Orsini ${ }^{2 *}$, Adriana Leico Oda ${ }^{3}$, Cristina CS Salvioni ${ }^{3}$, Acary SB \\ Oliveira ${ }^{3}$, Mauricio Santanna Júnior ${ }^{4}$, Luciana Moisés Camilo ${ }^{4}$, Brian França dos Santos ${ }^{5}$, Carlos \\ Henrique Melo Reis ${ }^{6}$, Marco Antonio Araujo Leite ${ }^{7}$, Marco Azizi ${ }^{5}$, Adalgiza Mafra Moreno ${ }^{5}$, \\ Cristiane Sousa Nascimento Baez Garcia ${ }^{4}$, Victor Waldhelm Cozer $^{7}$ and Carlos Eduardo Cardoso ${ }^{8}$
}

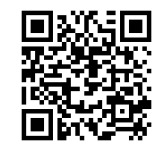

${ }^{1}$ Neuroimmunology Department, UFRJ, Brazil

${ }^{2}$ Iguaçu University, UNIG and Department of Neurology and Neurosurgery, Federal Fluminense University, UFF, Vassouras University, USS, Brazil

${ }^{3}$ São Paulo Federal University, UNIFESP, Brazil

${ }^{4}$ Federal Institute of Rio de Janeiro, IFRJ, Brazil

${ }^{5}$ Iguaçu University, UNIG, Brazil

${ }^{6}$ Hospital Geral da Posse and Iguaçu Uniiversity , UNIG, Brazil

${ }^{7}$ Medicine School and Neurology and Department of Neurosurgery, Federal Fluminense University, Brazil

${ }^{8}$ Vassouras University, USS, Brazil

*Corresponding author: Marco Orsini, Professor Miguel Couto Street - ZIP CODE: 24230240 - Rio de Janeiro -Niterói -CEP:

24230240, Brazil

\begin{tabular}{|c|c|}
\hline ARTICLE INFO & Abstract \\
\hline Received: 㸷 May 06, 2020 & Citation: Guilherme Gomes A, Marco O, Adriana Leico O, Cristina CS S, Acary SB O, et al., \\
\hline Published: 彗 May 15, 2020 & $\begin{array}{l}\text { Control of Respiratory Diseases in Patients with Amyotrophic Lateral Sclerosis During } \\
\text { the COVID-19 Pandemic. Biomed J Sci \& Tech Res 27(4)-2020. BJSTR. MS.ID.004542. }\end{array}$ \\
\hline
\end{tabular}

\section{Short Communication}

Persons older than 60 with hypertension, diabetes, COPD, cardiovascular, cerebrovascular, liver, kidney, and gastrointestinal diseases are more susceptible to the infection by SARS-CoV-2 and experience higher mortality when they develop COVID-19 [13]. COVID-19 cases with pre-existing COPD, or complicated by secondary bacterial pneumonia, are more severe and this may be due to complex immune pathogenesis[4]. Acute exacerbation of COPD has an intimate relationship with respiratory tract virus infection5. The prevalence of SARS-CoV-2 infection in COPD patients is not clear, but smokers and COPD patients are more susceptible to the infection of middle east respiratory syndrome coronavirus (MERS-CoV). MERS-CoV does the dipeptidyl peptidase IV (DPP4) such as a receptor, that had a higher expression in smokers and
COPD patients than in non-smokers [5,6], showing a correlation with smokers and a coronavirus specie.

Asthma and chronic obstructive pulmonary disease (COPD) are associated with chronic inflammation of the respiratory tract. Asthma affects about $10 \%$ of adults and an even greater proportion of children. COPD affects about $10 \%$ of people over 40 years of age [7]. Amyotrophic lateral sclerosis (ALS) and asthma are an possible association. ALS is a complex pathology involving many factors and signaling pathways, such as oxidative stress, dysfunction of mitochondria, altered intracellular protein traffic, protein aggregation, and glutamate excitotoxicity related with a reduction in the expression of glutamate transporters, apoptosis, proinflammatory cytokines and deficiency of cholinergic synapses 
[8-11]. Asthma is a chronic inflammatory disease with complete and/or parcial reversible airway obstruction and nonspecific airway hyper-reactivity asthma, there is a characteristic pattern of inflammation (type 2 immunity) [12] usually characterized by allergic inflammation with increased production of IgE by B cells, mast cell degranulation and eosinophil infiltration orchestrated by TH2 cells, but the same pattern of inflammation may also occur in non-allergic individuals [13].

Neurodegenerative disorders have the neuro-inflammation as characteristic of the pathologically affected tissue. There is extensive evidence that neurons and immune cells communicate, his interactions are involved in the lung inflammation of asthmatic patients $[14,15]$. Thereby, patients with both comorbidities (ALS and asthma and/or COPD) need a special managed according to its symptoms and severity, to decrease the clinical exacerbations, improve pulmonary function, and reduce morbidity. Although there aren't direct correlations, the similar multifactorial triggers, and the critical roles of neuronal inflammation, suggest that patients with ALS and asthma and/or CPOD must to be differential attention during the covid-19 pandemic.The major risk factor for COPD in western countries is cigarette smoking. COPD is a syndrome by progressive airflow obstruction, affecting peripheral airways, which leads to air trapping, dynamic hyperinflation and shortness of breath on exertion. In some patients, there are features of both diseases, and this has been termed asthma-COPD overlap syndrome $[16,17]$ both are characterized by chronic inflammation of the respiratory tract, although the nature of the inflammation and its location differ18. Patients with COPD have a different pattern of inflammation (type 1 and type 3 immunity) [19,20]. This inflammation is an amplification of the mucosal inflammatory response to inhaled irritants, such as tobacco.

Approximately six million people worldwide die due to tobacco use each year [21]. The cigarette contributes to the pathogenesis and a recognized risk factor of chronic obstructive pulmonary disease (COPD), hypertension, cardiovascular disease, cancer, chronic systemic diseases with inflammatory components such as atherosclerosis, Crohn's disease, rheumatoid arthritis, psoriasis, Graves' ophthalmopathy, and noninsulin-dependent diabetes mellitus [22,23]. The cigarette smoke promotes inflammation by inducing the production of pro-inflammatory cytokines, such a TNF- $\alpha$, IL-1, IL-6, IL-8 and granulocyte-macrophage colonystimulating factor (GM-CSF), and increasing the accumulation of immune cells in the airway $[24,25]$. Studies in vitro provide evidence for its immunosuppressive properties [22,26,27], which is demonstrated to increased susceptibility towards respiratory tract infections, bacterial meningitis, periodontitis and poorer wound healing $[22,23,28]$.

Recently, a histopathological study with 4 patients in posmortem presented a minucious lungs examination showing a bilateral diffuse alveolar damage with a comparatively mild-to- moderate lymphocytic infiltrate, composed of a mixture of CD4+ and CD8+ lymphocytes. The dominant process in all cases was consistent with diffuse alveolar damage, with a mild to moderate mononuclear response consisting of notable CD4+ aggregates around thrombosed small vessels, and significant associated hemorrhage [29].

Therefore, the previous extensive medicine and immunological knowledge provide us with the understanding that carriers of neurodegenerative diseases and his extensive association with lung dysfunction may be a severe risk factor to COVID-19 and pulmonary complications, principally, when tobacco's associated or not to COPD and/or asthma. Neuromuscular Disorders (NMD) can affect breathing function, but do not in general damage lung tissue, impaired breathing in NMD is due to weak diaphragm and breathing muscles. Thus, the strong physician's presence, nurses and caregivers in the pandemic process and in the search for measures to stop smoking are of paramount importance, because the cigarette smoke alters many signaling pathways, immune responses and increases the chance of complications in a covid-19 infection.

\section{Conflict of Interest}

No conflict of interest.

\section{References}

1. Arentz M, Yim E, Klaff L, Lokhandwala S, Riedo FX, et al. (2020) Characteristics and outcomes of 21 critically Ill patients with COVID-19 in Washington State. JAMA

2. Team TNCPERE (2020) The Epidemiological characteristics of an outbreak of 2019 novel coronavirus diseases (COVID-19) - China, 2020. China CDC Weekly 2: 113-122.

3. Zhou F, Yu T, Du R, Fan G, Liu Y, et al. (2020) Clinical course and risk factors for mortality of adult inpatients with COVID-19 in Wuhan, China: a retrospective cohort study. Lancet.

4. Bousquet J, Akdis C, Jutel M, Bachert C, Klimek L, et al. (2020) Intranasal corticosteroids in allergic rhinitis in COVID-19 infected patients: An ARIA-EAACI statement. Allergy.

5. Kurai D, Saraya T, Ishii H, Takizawa H (2013) Virus-induced exacerbations in asthma and COPD. Front Microbiol 4: 293

6. Seys L, Widagdo W, Verhamme FM (2018) DPP4, the Middle East Respiratory Syndrome Coronavirus Receptor, is Upregulated in Lungs of Smokers and Chronic Obstructive Pulmonary Disease Patients. Clin Infect Dis 66: 45-53.

7. Barnes PJ, Burney PG, Silverman EK, Celli BR, Vestbo J, et al. (2015) Chronic obstructive pulmonary disease. Nat Rev Primers 1: 15076.

8. Bondy SC, Lee DK (1993) Oxidative stress induced by glutamate receptor agonists. Brain Res 610 (2): 229-233.

9. Calvo AC, Manzano R, Mendonca DM, Munoz MJ, Zaragoza P, et al. (2014) Amyotrophic lateral sclerosis: A focus on disease progression. BioMed Res Int : 925101.

10. Menzies FM, Cookson MR, Taylor RW, Turnbull DM, ChrzanowskaLightowlers ZM, et al. (2002) Mitochondrial dysfunction in a cell culture model of familial amyotrophic lateral sclerosis. Brain 125(Pt 7): 15221533.

11. Vucic S, Kiernan MC (2009) Pathophysiology of neurodegeneration in familial amyotrophic lateral sclerosis. Curr Mol Med 9(3): 255-272. 
12. Ebbo M, Crinier A, Vely F, Vivier E (2017) Innate lymphoid cells: major players in inflammatory diseases. Nat Rev Immunol 17: 665-678.

13. Barnes PJ (2011) Pathophysiology of allergic inflammation. Immunol Rev 242: 31-50.

14. Renz H (2001) Neurotrophins in bronchial asthma 2: 265-268.

15. Renz H (2001) The role neurotrophins in bronchial asthma 429: 231237.

16. Postma DS, Rabe KF (2015) The asthma-COPD overlap syndrome. N Engl J Med 373: 1241-1249.

17. Barnes PJ (2016) Asthma-COPD overlap. Chest 149: 7-8.

18. Barnes PJ (2017) Cellular and molecular mechanisms of asthma and COPD. Clin Sci 131: 1541-1558.

19. Hogg JC, Fanny Chu, Soraya Utokaparch, Ryan Woods, W Mark Elliott, et al. (2004) The nature of small-airway obstruction in chronic obstructive pulmonary disease. N Engl J Med 350: 2645-2653.

20. Brusselle GG, Joos GF, Bracke KR (2011) New insights into the immunology of chronic obstructive pulmonary disease. Lancet 378 : 1015-1026

21. (2015) WHO, WHO Global Report on Trends in Prevalence of Tobacco Smoking; WHO, Geneva, Switzerland.

22. Sopori M (2002) Effects of cigarette smoke on the immune system. Nat Rev Immunol 2: 372-377.

ISSN: 2574-1241

DOI: 10.26717/BJSTR.2020.27.004542

Marco Orsini. Biomed J Sci \& Tech Res

(C) (P) This work is licensed under Creative

Submission Link: https://biomedres.us/submit-manuscript.php
23. Stampfli MR, Anderson GP (2009) How cigarette smoke skews immune responses to promote infection, lung disease and cancer. Nat Rev Immunol 9: 377-384.

24. De Boer WI, Sont JK, Van SA, Stolk J, Van Krieken JH, et al. (2000) Monocyte chemoattractant protein 1 , interleukin 8 , and chronic airways inflammation in COPD. J Pathol 190: 619-626.

25. Doz E, Noulin N, Boichot E, Guenon I, Fick L et al. (2008) Cigarette smoke-induced pulmonary inflammation is TLR4/MyD88 and IL-1R1/ MyD88 signaling dependent. J Immunol 180: 1169-1178.

26. Takahashi HK, Iwagaki H, Hamano R, Yoshino T, Tanaka N, et al. (2006) Effect of nicotine on IL-18-initiated immune response in human monocytes. J Leukoc Biol 80: 1388-1394.

27. Nizri E, Irony-Tur-Sinai M, Lory O, Orr-Urtreger A, Lavi E, et al. (2009) Activation of the cholinergic anti-inflammatory system by nicotine attenuates neuroinflammation via suppression of Th1 and Th17 responses. J Immunol 183: 6681-6688.

28. Nuorti JP, Butler JC, Farley MM, Harrison LH, Mc Geer A, et al. (2000) Cigarette smoking and invasive pneumococcal disease. Active Bacterial Core Surveillance Team. N Engl J Med 342: 681-689.

29. Sharon E Fox, Aibek Akmatbekov, Jack L Harbert, Guang Li, J Quincy Brown, et al. (2020) Pulmonary and Cardiac Pathology in Covid-19: The First Autopsy Series from New Orleans medRxiv 2020.04.06.20050575.

$\begin{array}{ll}\text { BIOMEDICAL } & \text { Assets of Publishing with us } \\ \text { RESEARCHES } & \text { - Global archiving of articles } \\ & \text { - Immediate, unrestricted online access } \\ & \text { - Rigorous Peer Review Process } \\ & \text { - Anthors } / / \text { biomedres.us/ }\end{array}$

